\title{
A FROGHOPPER ON SUGAR-CANE IN BRITISH GUIANA.
}

\author{
By C. B. Williams, M.A., F.E.S., \\ Department of Agriculture, Trinidad.
}

In the course of an investigation of the froghoppers (CERCOPIDAE) of Central America, made on behalf of the Government of Trinidad, I visited British Guiana in 1916. The object of the visit was to find, if possible, some new parasites for introduction into Trinidad in order to combat the froghopper (Tomaspis saccharina, Dist.), which is the most serious pest of sugar-cane in the island. Although the species of froghopper found on the sugar-cane in British Guiana is different from the species in Trinidad, yet all the parasites found were already known in that island. However, the following notes on the British Guiana insect may be of some general interest.

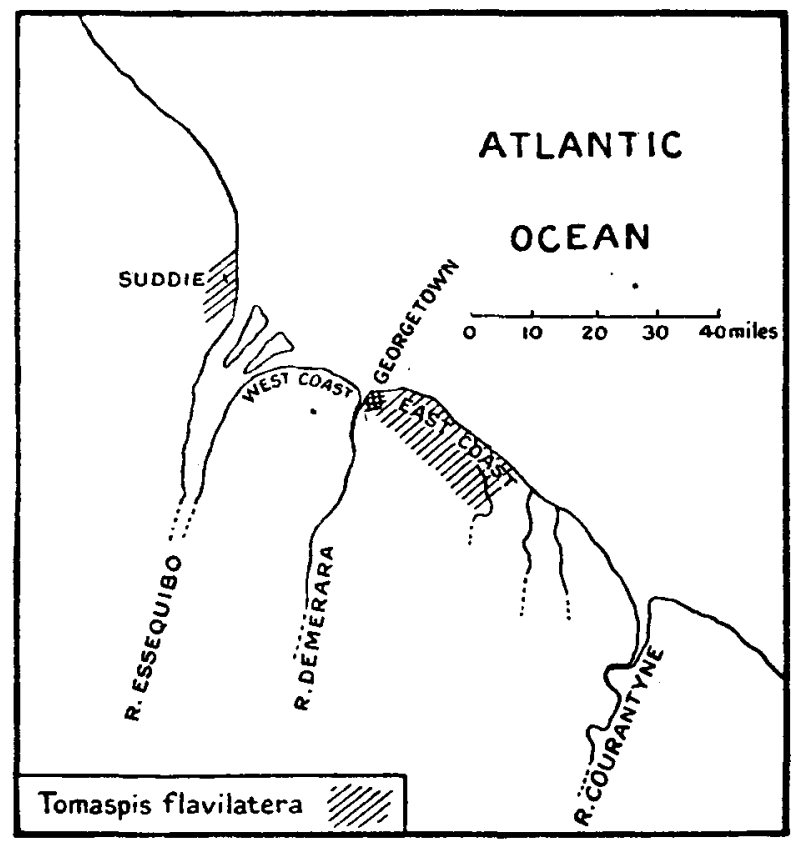

Fig. 1. Sketch-map of the coast of British Guiana, showing the distribution of the froghopper, Tomaspis flavilatera.

Practically all the investigation was carried out on the coast lands of what is generally known as Demerara. These were reclaimed many years ago from a flat forest swamp and are mostly below sea-level at high-tide. The soil is a deep alluvial deposit of clayey consistency. Drainage is bad and is done chiefly by sluices, which are opened by hand at low tide and closed again when the tide rises. The whole of the sugar-cane district is intersected with two systems of artificially constructed trenches or canals at different levels. The higher level is used for transport and 
irrigation or flooding, the lower system, usually about four feet below the other, is the drainage canal. In only one part of the coast under consideration is there any rise in the ground and this is just on the western side of the Essequibo River, where there are a few low sand ridges. The coast of Demerara proper (which extends from the Berbice to the Essequibo Rivers) (see map, fig. 1) is divided by the Demerara River into the East Coast and the West Coast ; the Corentyn Coast, east of the Berbice River was not visited.

The following is the average for 32 years of the rainfall at the Botanic Gardens, Georgetown, Demerara :

Jan. Feb. Mar. April May June July Aug. Sept. Oct. Nov. Dec. Total

$\begin{array}{lllllllllllll}8.4 & 6.8 & 7.5 & 7.3 & 11.5 & 12 \cdot 1 & 10.6 & 6.3 & 3 \cdot 1 & 2.4 & 5.3 & 11.5 & 91.3\end{array}$

During these 32 years the total annual rainfall has varied from 59 to 135 inches.

It will be seen that there are two dry seasons, one during February, March and April, and a second from about the middle of August to the middle of November.

The coast land is almost entirely under cultivation, that nearest the sea, immediately behind the sea defences, being largely used for rice-growing (the area under which is increasing every year), and very wet pastures for cattle, sheep and goats. Behind this, usually from about two miles to about eight miles from the sea, are the chief sugar fields. These stretch further inland up the river margins. A small area near Georgetown, once in sugar, is now used by market-gardeners. There is very little uncultivated land. Most of the wild plants are grasses and sedges, which are found in the pastures along the canal banks and roadsides, and to a lesser extent among the canes.

\section{The British Guiana Froghopper.}

The froghopper found attacking the sugar-cane along this coast is Tomaspis flavilatera, Urich. It has not yet done any serious damage, but is viewed with suspicion by the planters after what has been experienced in Trinidad.

They were first discovered by Mr. J. J. Quelch at Plantation Melville, East Coast, about 1909. In 1911 Mr. H. W. B. Moore reported that they were common only at Melville (Report for 1911, p. 20). They were found chiefly on grass and were preyed on largely by Attid spiders. In 1912 there was a long drought and the froghoppers almost disappeared, but in 1913 they were again seen on several estates, particularly Plantation Cane Grove, East Coast, and Plantation Ogle, East Coast. They were chiefly on the grass and less on the cane. (Moore, Report for 1913, p. 15.)

In 1914 Urich gave a short general account of froghoppers in the Journal of the Board of Agriculture of British Guiana for the use of the local planters. T. flavilatera is mentioned as occurring in British Guiana, but is not thought to be very serious. A list of the chief enemies of $T$. saccharina in Trinidad is given and it is suggested that most of them probably occur in British Guiana.

In 1914 " From June to August there was a fairly sharp attack. On some fields of Cane Grove over 50 nymphs of various ages. . . . . were counted attached to the rootlets of some stools. Froghoppers were also observed at Plantation Ogle, but the attack was not of much consequence. Numbers of nymphs were destroyed here by pounding and crushing " (Moore, Report for 1914, p. 15). In June of the 
same year Mr. Quelch bred out the parasitic Syrphid fly, Salpingogaster nigra, from maggots found at Cane Grove.

In 1915, froghoppers were abundant in July and August at Plantation Ogle; 386,222 nymphs were collected by hand and destroyed. "This is the first occasion on which it has assumed alarming proportions" (Moore, Report for 1915, p. 7). The fields were also flooded for some days and the nymphs which crawled up the stems were shaken off into the water; in this way many thousands were destroyed. The Syrphid fly was also found in this locality for the first time this year.

My first observations in the field were at the end of May and the beginning of June 1916, when Tomaspis flavilatera was found occasionally on several estates, but was nowhere common. Females in captivity readily laid eggs on dead trash (see below). The nymphs and adults were chiefly in the short succulent grass along the narrow drainage trenches running through the canes, and the adults could be readily caught by sweeping along these with a strong net.

After two months absence I returned to the district again in August and September, when the insects were much more numerous, but were still causing practically no damage. One estate (Plantation Ogle) had already started collecting the nymphs by hand.

During my two visits I found the froghopper generally distributed along the East Coast and in small numbers on a plantation just west of the Essequibo River. Although the West Coast was visited on several occasions, none were seen there, and I understood that neither Mr. Bodkin nor Mr. Moore have any record from this Coast. In spite of this I think there is no doubt that it will be found to occur there in small numbers.

\section{The Egg.}

Eggs were first obtained in captivity on the 3rd June 1916. They were laid in the dead moist leaf-sheaths at the base of the grass stems near the ground, in a position quite similar to that adopted by $T$. saccharina in Trinidad. In cane and in grasses with thick leaves the egg is inserted between the two surface layers with the anterior end very slightly projecting. In grasses with thin leaves the egg may be passed through one or more leaves and embedded in a deeper layer. In one case in which a thin dead leaf was covering some living tissue an egg was inserted through the dead layer into the green tissue beneath. This was the only case in which an egg was found in green tissue.

The eggs are pale yellow in colour when first laid. They are $0.88 \mathrm{~mm}$. long and $0.29 \mathrm{~mm}$. broad; spindle-shaped, slightly more pointed at the anterior than at the posterior end. After some days a dark longitudinal streak (the hatching lid) appears at he anterior end, quite similar to that found in Tomaspis saccharina.

\section{The Nymph.}

Stage I. Total length, 1-2.5 mm. Pale yellowish-brown, with a slight red-brown mark on either side of the abdomen. (The young larva of Tomaspis pubescens, the black froghopper, which is the only other grass-feeding species found in this district, can be distinguished at this stage by its orange-red colour; although occasionally occurring on grass, it was not found on sugar-cane.) No traces of 
wing rudiments are noticeable at the hind margin of either the meso- or meta-thorax. Owing to the misplacement of my preserved specimens of this stage, it is not figured.

Stage II (fig. 2, A). Total length, 3-3.5 mm. Yellowish brown in colour, thorax and head slightly darker than the abdomen. Head less than one and one-half times as long as broad, longer than the prothorax. Hind angles of the meso- and metanotum very slightly acute, indicating the wing rudiments. Antennae six-segmented; length of segments in millimetres: $-1,0.11 ; 2,0.08 ; 3,0.11 ; 4,0.07 ; 5,0.05$; $6,0.06$; total length of antenna, $0.50 \mathrm{~mm}$.

Stage III (fig. 2, B). Total length $4: 5-5 \mathrm{~mm}$. Colour as before, but the thorax and head are more distinctly darker than the abdomen. Head more than one and a half times as broad as long and about equal in length to the pronotum. Hind

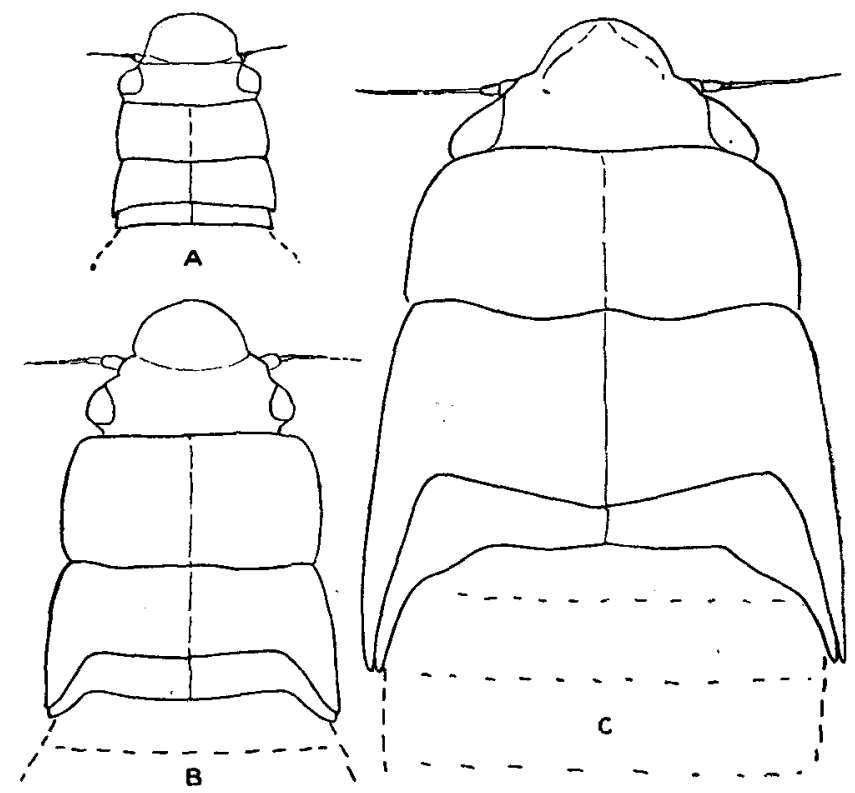

Fig. 2. Head and thorax of nymph of Tomaspis favilatera : A, stage ii.; B, stage iii ; C, stage iv.

angles of the meso- and meta-notum produced into wing rudiments, which are about as long as wide at the base. Antennae seven-segmented; length of segments in millimetres :- $1,0 \cdot 19 ; 2,0 \cdot 13 ; 3,0 \cdot 16 ; 4,0 \cdot 10 ; 5,0 \cdot 10 ; 5,0 \cdot 10 ; 6,0 \cdot 06 ; 7,0 \cdot 10$; total length of antenna, $0.85 \mathrm{~mm}$.

Stage IV (fig. $2 \mathrm{C}$ ). Total length 7-8 mm. Head and thorax much darker than the abdomen, wing rudiments still darker. Head more than:twice as broad as long and shorter than the pronotum. Wing-rudiments reaching to the hind magrin of the second abdominal segment. Antennae eight-segmented; lengths of segments in millimetres:- $-1,0 \cdot 19 ; 2,0.18 ; 3,0.27 ; 4,0 \cdot 18 ; 5,0.21 ; 6,0.08 ; 7,0.13$; $8,0 \cdot 10$; total length of antenna, $1.35 \mathrm{~mm}$.

The nymphs in all stages are found in their masses of frothy secretion on the roots of grasses or sugar-cane on or just beneath the surface of the ground. If the 
ground is loose and open, they descend lower; usually however the great majority are within three inches of the surface. The froth of Tomaspis flavilatera closely resembles that of $T$. saccharina in Trinidad. It is softer and less elastic than that of $T$. pubescens, the only other froghopper found on grass in this district.

Just before emergence the full-grown nymph frequently ascends a grass stem to a height of from six to ten inches and there forms a frothy covering in which the final moult takes place. In the early morning these elevated froth masses are often seen, but it is only at this stage that the nymph is found away from the roots. 'This distinguishes it in habits from the froghopper (Tomaspis tristis, F.) at present found on sugar-cane in Surinam, which regularly forms its froth at a height of two to five feet above ground level (Williams 1916). This latter species is known to occur in British Guiana and might at any time be found on sugar-cane.

\section{The Adult.}

Tomaspis flavilatera was described by Urich in 1914 (Bull. Ent. Research, v, p. 43) from specimens taken in British Guiana; at present it is not known elsewhere. It is dark brown in colour, with the fore wings semi-translucent. On the costa of each fore wing is a light yellowish-brown streak from the base of the wing almost to the apex. This species is quite different in the scheme of coloration from $T$. saccharina. and its various relatives in Central America, all of which have as a colour pattern two more or less complete light transverse bands on a dark ground. In the minuter structure, in the profile of the face, in the structure of the male genitalia and in habits, it shows a very close relationship to this group of froghoppers and must be considered as a member of the saccharina series with an aberrant colour pattern.

Among a large number of specimens examined there is very little variation. The only distinct form is one in which the eyes are bright red instead of the usual black. This is rare and appears to be in a proportion of $1: 1000$, or less. A similar variety occurs in other species which will be dealt with later.

During the day-time the adults may be found in large numbers sitting on the short succulent grass growing along the drainage trenches. They are found also in the axils of the upper leaves of the cane plants, but they do not frequent this situation so exclusively as is found to be the case with Tomaspis saccharina in Trinidad.

In addition to sugar-cane almost any species of grass seems to be used as food by T. flavilatera. The following grasses on which nymphs were found have been identified :-Cynodon dactylon (Bermuda or Bahama grass), Cynodon sp., Stipa sp., and Panicum lascum. Adults were also seen in the rice plantations sucking the stems of rice. There is, however, not much danger of its becoming a pest of the wet land rice, as conditions at the root of the rice are quite unsuitable for the nymphs.

\section{Natural Enemies.}

During the months of August and September the following natural enemies were seen. Of these only the Syrphid fly (Salpingogaster nigra) had been previously recorded as attacking $T$. flavilatera.

\section{Egg Parasites.}

(1) The Vermilion Parasite (Oligosita giraulti). Several specimens of this minute Chalcid were obtained during September 1916 from grass containing froghopper 
eggs collected at Plantation Ogle, East Coast, and one specimen was obtained by sweeping the grass in the same locality.

(2) Haplothrips sp. In one of my small breeding tubes containing only froghopper eggs in dry trash I found a larva of a thrips which, under these artificial conditions, was sucking the contents of the eggs. The larva was bred out and the adult proved to be a species of the genus Haplothrips, a very abundant and widely distributed genus of thrips, members of which have been previously reported to be occasionally carnivorous ;* as a general rule, however, they are vegetarians. No effort was made to introduce this insect into Trinidad, as several species of the genus are already quite abundant there and it is questionable if they are of any serious value under field conditions.

\section{Parasite of the Nymph.}

(3) The Syrphid Fly (Salpingogaster nigra). This was first recorded from British Guiana by Quelch in 1914. During my visit in Mav and June it was not seen, but by the middle of August the maggots were quite common at Plantation Ogle, and a. few were seen at Cane Grove and Non Pareil, all localities on the East Coast. By the middle of September there was a Syrphid maggot on nearly every cane stool in that part of Plantation Ogle where the froghoppers were abundant.

\section{Parasites of the Adult.}

With the exception of the Green Muscardine fungus no true parasite of the adult froghopper was found, but a number of predatory insects and lizards were observed to feed on froghoppers to a greater or less extent.

(4) The Green Muscardine Fungus (Metarrhizium anisopliae). In the course of over two months spent in this district only a single adult froghopper infested with this fungus was found. This was on the 14th August 1916 at Plantation Ogle. No infected nymphs were observed. This was entirely unexpected, when compared with its relative abundance in Trinidad, and when one considers the moist conditions in the cane-fields, which seemed extremely favourable for its propagation. In the event of further trouble with this froghopper in Demarara, cultures should be obtained from Trinidad and an attempt made to get it well established. It could not fail to be of some value, as among its known hosts are included the smaller sugar-cane borers (Diatraea spp.).

(5) Dragonflies. Owing to the number of small drains with which the cane-fields of Demerera are intersected, dragonflies are extremely abundant. One large green specimen when captured readily took a froghopper adult, and as the dragonflies are continually resting on and hawking above the short grass on which the froghoppers are abundant, there is little doubt that they feed on them in the wild state.

(6) Attid Spiders of several species were common and several times were seen in the act of feeding on froghoppers.

(7) Two species of predatory ants were observed carrying away adult froghoppers, but the froth of the nymphs seems to render them immune from attack. On more than one occasion hunting ants invaded my bench and killed all adult froghoppers

* In Panama in 1917 I found another species of the same genus feeding on froghopper eggs under similar conditions. 
and parasites in my breeding cages. In every case, however, the nymphs were found untouched.

(8) Heza peramata, Kirby. A family of nymphs of this large Reduviid was found at Ogle in the axil of a cane leaf. They readily ate froghoppers in confinement and most probably do so in the field, as the position in which they were found is that frequently sought for by the adult froghoppers. They were not introduced into Trinidad, as Mr. Urich, Entomologist to the Board of Agriculture, Trinidad, informed me that they already occurred there.

(9) Zelus mimus, Stail. The species is smaller and more active than the previous one and was frequently seen flying about and resting on the short grass along the drains in the cane-fields. It was observed on several occasions feeding on froghoppers in the wild state. Mr. Urich informed me that this species also is known in Trinidad.

(10) Pflugis mantispa, Bol. This active predaceous grasshopper was not uncommon in the traces between the cane-fields. It was already known in Trinidad as a froghopper enemy, but does not seem to frequent the cane-plots to any great extent.

(11) Xiphidium propinquum, Redt. This grasshopper, which is largely insectivorous, was abundant on most of the sugar-cane estates. Like the last species, however, it is mostly confined to the grass on the traces. On several occasions it was seen to eat adult froghoppers, but on the other hand the newly hatched Xiphidium were found to eat readily small parasitic Hymenoptera, including the vermilion eggparasite (see above), and the same grasshopper was found damaging the flowers of rice at the Georgetown Botanic Gardens. A related species of Xiphidium was studied in Hawaii and found to be partly vegetarian and partly predaceous, including among its prey the sugar-cane leaf-hopper.

(12) Lizards appeared to be more abundant in the cane-fields here than in Trinidad; this may be partly due to the scarcity of the mongoose (see below).

(13) Birds. The following birds occurring in British Guiana were seen on the sugar-cane fields there or have since been proved by dissection in Trinidad to feed on froghoppers :-

Tyrannidae (Tyrant Flycatchers).

Tyrannus melancholicus (Grey-headed Kiskadee).

Muscivora tyrannus (Scissors-tail Flycatcher).

Fluvicola pica (Cotton Bird, Widow).

Arundinicola leucocephala (White-headed Widow).

Cuculidar (Cuckoos).

Crotophaga ani (Old Witch Bird, Tick Bird).

ICTERIDAE (Mocking Birds).

Icterus xanthorous (Yellow Plaintain Bird, Carouge).

Quisqualus lugubris (Boat-tail, Black Bird, Golden Eye).

Fringillidda (Finches).

Volatina jacarina (Black Dancing Finch).

Everything possible should be done to encourage these, and all other insectivorous birds, in the cane-fields. Most of the cane districts are very bare of trees ; the planting of bushy trees along the traces would be an advantage. 
(14) The Mongoose. This animal, which is sometimes considered as indirectly responsible for the abundance of the froghopper in Trinidad, has unfortunately been introduced here also. It is however not common, the general reason given for this being that the low level of the land causes any burrows that it makes to be immediately filled with water. On one estate the manager informed me that the mongoose had got over this difficulty by making its burrows in the mounds of earth heaped up to form approaches to the small bridges over the canals.

Although work at present being carried on in Trinidad shows that the mongoose is much more insectivorous in its diet than was apparently ever suggested, yet there is no doubt that on the whole it is an undesirable animal, and it is to be hoped that steps will be taken to prevent it reaching the hinterland of the Colony, where it might do very serious damage.

\section{Artificial Control.}

The means adopted for the control of this froghopper, previous to my visit, consisted in flooding the land and hand-picking the nymphs. It has been mentioned above that at Plantation Ogle in 1915 over 380,000 nymphs were collected. This was done by the regular insect gang of the estate, which at normal times is employed in collecting the grubs of the sugar-cane moth borers (Diatraea and Castria). Flooding may be done for a few days as a temporary control measure, but in some

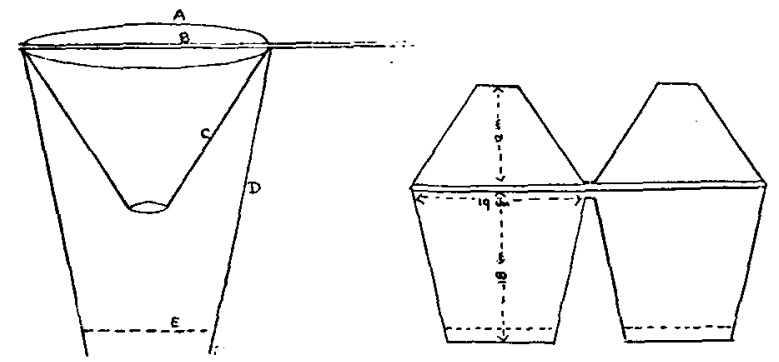

Fig. 3. Sweep-net for catching froghoppers ; explanation in the text.

cases an uncultivated field is kept under water for a year or eighteen months. This treatment is found to have a beneficial effect on the soil, as well as preventing these uncultivated areas from becoming breeding grounds for insect pests.

As the adults were found so commonly sitting on the short grass in the drains, I decided to see if they could not be caught on a large scale by the use of sweep-nets. Several forms of net were tried, but the one described and figured was finally. adopted and proved extremely successful.

The net (fig. 3) consisted of a bamboo handle (B) going right across a stout wire ring (A), thus giving considerably increased strength to the ring, which was about one foot in diameter. The bag, made of a light canvas, was double, the inner bag (c) in the form of a funnel open at the end to allow the insects to get into the main bag, but preventing their escape. The outer bag (D) was also not stitched across the end but instead a piece of strong mosquito netting was inserted about two inches from the end and fastened all round to the canvas. This piece of net was important 
for two reasons: (1) it allowed a current of air to pass through the net when in use, so that insects were not blown away from the net by the draught created; (2) it allowed the escape of the small parasites which would be swept up by the net. The edges of the outer bag were always allowed to project for the two inches beyond the mosquito net in order to protect it from wear and tear. The inner and outer bag could be cut from one piece of canvas as shown in the second figure. The part of the net which passes round the ring is best reinforced with stout webbing. Even the strongest net bag was usually worn out after one or two week's continual use.

The boys walked down the drains through the cane-fields sweeping the grass on either hand. About every twenty minutes (usually at the end of a drain) the net was squeezed in the hand to incapacitate the contained insects, which were then removed (by putting the hand through the central funnel bag) and transferred to a tin box. In this way boys were able to catch $3,000-4,000$ adult froghoppers in a very short working day of not more than 5 hours. The largest number actually brought in when I was there was 3,600 ; but supervised sweeping on one drain, which had already been swept about two hours previously, produced 500 hoppers in 20 minutes, so that an average of 1,000 an hour ought easily to be reached.

The boys were offered two cents (1d.) per hundred. During September 1916 at Plantation Ogle two to ten boys collected on twenty-two days and caught 533,540 adults. During the same period 540,000 nymphs were hand-picked, but this required a larger gang, and a higher price ( 4 to 5 cents per hundred) had to be paid. During the year 1916 over 4,000,000 adults and nymphs were destroyed at Plantation Ogle on an infested area of about 30 acres.

Several hundred specimens from the sweep-nets were taken at random and the sex determined; as a result 46 per cent. were found to be females.

Two light traps were tested in comparison, one an oil lamp and one an acetylene light. The former caught 525 and the latter 651 froghoppers in one night. Five hundred of each of these were sexed and gave in each case 494 males and 6 females, or 1.2 per cent. of females. It will also be noticed that the bright light is but very little better than the oil lamp. These results agree absolutely with experiments made in Trinidad.

It will be seen that the method of sweeping is far more efficacious than the use of light traps.*

\section{General Conclusions and Summary.}

At the time of my visit (1916) the froghopper could not be considered as a very serious pest of sugar-cane. It was in some spots extremely abundant in the fields, but by far the larger number were feeding on the grass. Even at its worst the numbers nowhere approached those found in Trinidad during an attack, and the canes suffered very little visible damage. It would, however, be very difficult to distinguish the present conditions in British Guiana from those that must have prevailed in Trinidad before the insect became a regular pest. In view of this, the froghopper should always be regarded as a possible great danger in Demerara, and any reasonable precautions and preventive measures should be taken.

* This remark applies only to British Guiana. In Trinidad, owing to slight differences in habit of the insect and in cultivation, the sweep-nets are quite useless. 
The following are, I believe, the chief reasons why up to the present the froghopper has done so little damage in Demerara as compared with Trinidad.

(1) The conditions of climate and cultivation in Demerara favour a continual regular existence of the froghopper and its parasites throughout the year. The absence of any long dry season together with the low level of the land makes the fields always quite damp in some spots at least. This is particularly noticeable in the narrow drains which occur at intervals of about six yards throughout the canes and which have, even in the driest season, an edging of green succulent grass. Between these drains the earth is banked up into high ridges on which the cane is planted; and these ridges are frequently too dry to attract the froghoppers from the moist drains. As a result the froghoppers may be very abundant in the drains, while the canes, except perhaps those bordering on the drains, are untouched.

(2) The lesson learnt by the planters of Demerara from the invasion of the large moth borer (Castnia licus) has resulted in each estate having an organised insect gang always at work, and as, in addition, they know from the unfortunate experience of Trinidad that froghoppers are capable of serious harm, the slightest trace of them in a field is reported and extremely energetic measures taken for their extermination. In this way more money is expended in destroying them than the actual damage caused, but the expenditure is more than justified as an insurance policy.

(3) One of the most effective ways of dealing with the froghopper outbreaks in Demerara is the flooding of the fields; a control measure quite impossible in Trinidad.

(4) The mongoose is still comparatively scarce.

(5) Although on some estates quite a large proportion of the canes are burnt before cutting, on account of the scarcity of labour, yet cutting is not confined to one season, as in Trinidad, and there are always standing canes forming shelters. In addition, burning, where practised, is always done at night when the ground is wet with dew, or on moist days; as a result it is not severe, the trash on the ground and the grass in the drains remain, and the eggs and their parasites survive.

(6) There is, in comparison with Trinidad, very little uncultivated land to serve as a source of infestation.

The list of enemies of the froghopper in Demerara is practically the same as in Trinidad, and with the exception of the green muscardine fungus, there is little that could be introduced. Any new parasite obtained for Trinidad should however be useful also in Demerara.

In addition to Tomaspis flavilatera, several other species of the genus Tomaspis were found in British Guiana. As in most cases the identity of these is not yet settled, particulars are reserved for a later date.

\section{References.}

H. W. B. Moone. General Report on Insect Pests for the year 1911 to Messrs. Curtis Campbell \& Co. and Messrs. Booker Bros. Mc.Connell \& Co., Georgetown, Demerara (1912) p.

Ditto for 1913 (1914) p. 15.

Ditto for 1914 (1915) p. 15.

Ditto for 1915 (1916) p. 7.

Ditto for 1916 (1917) p. 9 . 
A FROGHOPPER ON SUGAR-CANE IN BRITISH GUIANA.

J. J. Quelch. General Report on Insect Pests to Messrs. Curtis Campbell \& Co. Messrs. Booker Bros. \& Co., June 1911, p. 2.

F. W. UrrCH (i). Froghoppers.-Jl. Board Agric. British Guiana, vii, No. 3, Jan. 1914, pp. 148-151.

F. W. URICH (ii). Description of a new Froghopper from British Guiana.-Bull. Ent. Research, v, 1914, p. 43.

C. B. Wilurams. Notes on a Froghopper attacking Sugar-cane in Surinam.Bull. Ent. Research, vii, 1916, pp. 271-2. 